\title{
ASSESING BUSINESS ETHICS IN CONTEXT OF CORPORATE SOCIAL RESPONSIBILITY
}

\begin{abstract}
SUMMARY
Introduction. Under the current economical and globalization conditions, companies in Latvia have to be aware of the importance of the enterprises'social responsibility in the formation of a successful long term development, efficient working environment and company's publicity.

Aim of the Study. This study investigates the relationship between organizational values and sensitivity to corporate social responsibility among current employees and business students.

Materials and Methods. This study investigates the relationship between organizational values and sensitivity to corporate social responsibility among current employees and business students. Using questionnaire of values' orientations and test of business ethic development, survey data was collected from employees and business students.

Results. The results of the study reveal some employee groups that are remarkably different in relation to social responsibility, as well as practicing workers and managers have more social responsible values than current business students.

Conclusions. The necessity to facilitate the role of social responsibility in the society and entrepreneurship environment has to be placed at the top of the list of the tasks for higher educational institutions.
\end{abstract}

Key words: social responsibility, enterprises' social responsibility, business ethics

\section{INTRODUCTION}

Over the last decades, it has become obvious that no extensive and perspective development of economics is possible without due consideration of moral (McIntosh, Thomas, Leipziger, Gill, 2003; Robbins, 1997; Siccone, 1998; Garleja, Vidnere, 2000; Garleja, Vidnere, 2001; Milts, 2000). Economics is becoming more productive if maximum attention is focused on the principles of ethics. Moral factors are the causes of both - ecological and economical recession, and it is difficult to find a moral non-related economical issue (Weyzig, 2009). Employment and unemployment, labor division, salary, property, budget distribution, proficiency, relationship between a seller and a customer, etc. are closely linked with the issues of justice, duty, personal development, freedom, rights, responsibility, conscience, respect and admiration, sense of life. It is important to note that the origin of moral is closely linked with economics.

Empirical studies of the dimension of management ethics research factors that influence ethical decision making, ethics of the action, spread and frequency of immorality in companies, correlation between values and management success, acceptance of unethical management by employees. A number of researchers have pointed out that activities of people with strong values tend to be more ethical than they are usually expected. Nonetheless, unethical situations are 
common anyway (Scholtens, 2009; Perrinjaquet, Furrer, 2005; Hughes, Ginnett, Curphy, 1999). Unethical behavior is encouraged by the lack of understanding about ethics in the society as well as the fact that unethical activities lead to success.

\section{AIMS OF THE STUDY}

This study investigates the relationship between organizational values and sensitivity to corporate social responsibility among current employees and business students.

\section{MATERIALS AND METHODS}

On the management level, moral development is evaluated basing on the decision making process and the style of management accepted by the company (Velasqez, 2002). This analysis describes the ethical leader in connection with the moral development levels.

Ethical managers impersonate integrity; they are honest and fair; they stand for their beliefs; they are excellent communicators and possess persuasion skills. L. Paine says that they never permit lasting injustice and evil. The above kind of managers is neither hypocritical nor unfair. They avoid unacceptable influence and interest conflict. Leaders, who are worth admiring, never mislead and cheat the others. They openly and persistently perform their duties (Paine, 1997). A respectable leader has the courage to do what they think is right and good, and they stay out of what is not acceptable. They never sacrifice their moral principles for the sake of advantage. These leaders fight for what they believe in and what they accept, and they take full responsibility for their activities. In the eyes of their employees, successful leaders are recognized managers and authorities. They let their staff know what is expected from them and why. The issue of moral values is important in pedagogic. In the world, value education is gaining increasing significance. Opinions are present (Milts, 1999), that in the future, value education in schools will become as important as the native language or mathematics. Values enable us to look deeper into our lives. On the factual level, people might be rational objectivists. On the general level, conformities and concepts are sought and facts are selected. In the sense of entrepreneurship ethics, this means that the organizational system of values determines its strategy, structure and decision making (Paine, 1997). Moral forms the basis of public values. Moral is distinguished from other public phenomena by its specific values.

The basis of the research is employees of the small and medium size enterprises that represent the following activities: financial mediating; wholesale and retail; hotels and restaurants; real estate, lease and other kinds of commercial activities. Respondents to the survey $(n=618)$ are different levels of managers, experts, employees, service and sales personnel. The research does not include unskilled workers and people holding low position.

In order to obtain data for comparison, additional survey was carried among: 100 employees from state budget institutions (state and municipality management, State Revenue Service, the Bank of Latvia, educational institutions; 125 first year bachelor degree students from Business College - future employees of enterprises. The total of the respondents of the value orientation survey was 843.Description of the method: to obtain data basis through survey over a definite period of time so that the data basis can be processed by statistic data processing and analyses software Statistic 6 Statsoft Co. Survey contained:

1) value orientation survey, elaborated within the European partner states grant cooperation project

WACRA, in English, adjusted in Latvian (Garleja, Vidnere, 2001);

2) business ethics development test (Уткин, 1998), adjusted in Latvian.

The task of the respondent was, by using Likert scale method, to evaluate 91 statements 
- indicators given in the value orientation questionnaire that describe organizational phenomena, tendencies, principles and other criteria. Levels: 7 - extremely important; 6 -very important; 5, 4, 3 - important (by growing significance); 2 - of little importance; 1 - of very little importance. In E. Utkins business ethics test (Уткин, 1998), respondents had four options - Agree Completely, Agree Partly, Disagree Partly, Disagree Completely - to evaluate 10 company ethics sensitive situations.

\section{RESULTS}

The importance of honesty enjoys higher average evaluation by female respondents -170 or $29,67 \%$ females chose the answer 'extremely important', while the same evaluation was chosen only by $20,60 \%$ male respondents.

We can observe essential differences in the evaluation of honesty, if we single out students. $18-19$ year old first year students gave the category of honesty significantly lower evaluation. The average evaluation of the above category by the total of respondents $(n=840)$ was 5,62 points. Among them males $(n=42)$ evaluated honesty with 5,071, but female students $(n=83)$ - even 4,82 points.

Evaluation of honesty by age groups demonstrated ascending trend: each next age group gave higher evaluation.

Honesty evaluation data were subjected to disperse analyses in order find out the impact of the factorial features interaction. The analyses resulted in confirmation of the statistical significance.

Quality tests of business ethics test data confirmed correspondence of the data to the quality criteria. Results obtained correspond to the principle of regular distribution. Student t-test value $-2,587$ with $p=0,013$; Kolmagorov - Smirnov criteria test results: $d=0,132, p>0,20$.E. Utkins has provided interpretation of the test results: up to 5 points - excellent score; from 6 to 10 level of ethics high enough; from 11 to 15-medium developed ethics; from 16 to 26-perfection of moral is needed-from 27 to 30 danger! Respondents scored from 3 to 24 points. Results of E. Utkins business test for students of entrepreneur management program $(n=45)$ : average 12,98 with standard deviation 3,793 .

Table 1. Average results of business ethics test

\begin{tabular}{|l|l|l|l|}
\hline analytical group & $\mathbf{n}$ & average & SD \\
\hline males & 16 & 11,125 & 3,612 \\
\hline females & 29 & 14,000 & 3,547 \\
\hline
\end{tabular}

The average business ethics test results fell into the section that is defined by E. Utkin as 'level of ethics high enough'. The differences in business ethics test results confirm the importance of the gender factor which was found out in the course of disperse analyses. Average evaluation by male respondents is close to high level of ethics whose border is 10 points. However, on the average, female respondents are closer to the next lower business ethics level with medium developed ethics whose border is 16 points. The difference in the average score is $20 \%$.

The relatively lower business ethics level among female students clearly proves the tendency that showed in value orientation inquiry, where honesty was evaluated as ethical category. Likewise, evaluation by first year male students was by $5 \%$ higher than by female students. 


\section{Discussion}

The survey organized to find out how respondents evaluate importance of honesty as ethical category, identified statistically different analytical groups and helped to confirm an important theoretical statement which says that life experience is an important factor for personal ethical development, and therefore mastering moral values is a life long process.

Results of the research (see Table 2) showed the trend similar to the one present in the research carried out in 2002 by University of Lausanne which questioned entrepreneurship students and university graduates - currently managers of different levels.

Table 2. Results of Research

Average evaluation of honesty as ethical value $(\max 7)$

\begin{tabular}{|c|c|c|c|c|}
\hline Category & & $\mathbf{n}$ & average & SD \\
\hline \multicolumn{5}{|l|}{ Gender } \\
\hline & Males & 269 & 5,430 & 1,323 \\
\hline & Females & 572 & 5,702 & 1,252 \\
\hline \multicolumn{5}{|l|}{ Age } \\
\hline & Up to 30 & 417 & 5,438 & 1,356 \\
\hline & $30-44$ & 320 & 5,759 & 1,167 \\
\hline & $45+$ & 103 & 5,883 & 1,207 \\
\hline \multicolumn{5}{|l|}{ Education } \\
\hline & Secondary & 336 & 5,468 & 1,363 \\
\hline & Unaccomplished higher & 207 & 5,737 & 1,184 \\
\hline & Higher & 300 & 5,712 & 1,209 \\
\hline \multicolumn{5}{|l|}{ Company type } \\
\hline & Enterprise & 375 & 5,773 & 1,123 \\
\hline & Bank & 238 & 5,735 & 1,246 \\
\hline & State institution & 100 & 5,680 & 1,309 \\
\hline & 1 st year students & 125 & 4,904 & 1,467 \\
\hline \multicolumn{5}{|l|}{ Location } \\
\hline & Riga & 505 & 5,67 & 1,287 \\
\hline & Elsewhere in Latvia & 336 & 5,547 & 1,326 \\
\hline
\end{tabular}

Similar to the practical results of the promotion work, the Swiss research evidenced that corporate responsibility enjoyed higher evaluation among the managers than among the students (Perrinjaquet, Furrer, 2005). Evaluation of honesty as ethical category increased with every age 
group of the respondents to the value orientation inquiry; evaluation in every age group among female respondents was slightly higher than that by males of the respective age group. Out of all analytical groups, first year entrepreneurship students- both males and females - showed the most different evaluation of the category of honesty. Furthermore, opposite to the general tendency among females to give honesty a higher evaluation, female students were more modest in their conclusions: the average of the evaluation of honesty by males was $90 \%$ of the total of the respondents, by females - only $86 \%$. Business ethics development level test shows exactly the same gender difference with the same tendency - lower evaluation of honesty by female students. The results show (see Table 2) that the development of the first year students correspond to the respective age from 16 to 21 years for boys and from 15 to 20 for girls. The frame is extremely important in personal development. This makes us conclude, that, in general, moral development of first year students corresponds to the conventional stage defined by L. Kohlberg (Knowles, McLean, 1986). Apart from that, their social responsibility is in progress. Low evaluation of honesty as ethical category by students can be explained by lack of life experience. Hopefully, over the years when the young people will have to face and resolve moral dilemmas in their practical lives, they will experience ethical maturity, and this will help them develop into socially responsible people who will be able to implement the principles of socially responsible entrepreneurship. However, the process of the ethical development of youth should not be left without supervision. Personal experience might create one sided opinion about life, therefore, personal experience is not enough. It should be supplemented by the positive experience of history and society taught in general and higher education study courses and organizational staff trainings.

\section{CONCLUSIONS}

Honesty is the key provision for entrepreneurial success. Honesty ensures long term success. It is the sole way to make the company trustworthy. Trust is the capital that has to be sought. The necessity to facilitate the role of social responsibility in the society and entrepreneurship environment has to be placed at the top of the list of the tasks for higher educational institutions. The above assignment is closely related with two other tasks: 1) to develop understanding of the issues of ethics among students; 2) to facilitate development of moral obligations and attitude to personal responsibility.

Teaching the correct answers is not the main task of the courses of ethics offered by higher educational institutions. Universities and colleges have to prepare students for practical situations when they will have to resolve ethical dilemmas; they have to introduce the best moral acknowledgements, teach students how to lead successful discussions on ethical problems that they will face in their personal and professional lives. These tasks are very important, and they have to educate socially responsible managers impersonating high ideals and values.

Continuous development can be ensured solely by socially responsible entrepreneurship, therefore higher educational institutions have to take on responsibility for educating ethics conscious managers. In Latvia, economics and management study programs are offered by 21 higher educational institutions. Currently, 60 different programs of the aforementioned areas have been accredited. In order to implement the preconditions for socially responsible entrepreneurship and facilitate growth of the moral development of the future managers, higher educational institutions have to plan sufficient number of lessons in practical ethics - business ethics. The same refers to other study courses - by the help of situation analyses method, attention has to be focused on the ethical aspect of things, and solution of moral dilemmas should not be avoided. 


\section{REFERENCES}

1. Garleja, R., Vidnere, M. (2000) Psihologijas un sociālās uzvedības aspekti ekonomikā [Aspects of Psychology and Social Behavior in the Economics]. I daļa, Rīga: RaKa, 264 lpp. (in Latvian).

2. Garleja, R., Vidnere, M. (2001) Psihologijas un sociālās uzvedības aspekti ekonomikā [Aspects of Psychology and Social Behavior in the Economics]. Testi I, 1. daļa, Rīga: RaKa, 317 lpp. (in Latvian).

3. Vidnere, M. (2001) Vadības sociologija un psihologija [Sociology and Psychology of Management]. Rīga: Mācību apgāds, 120 lpp. (in Latvian).

4. Hughes, R., Ginnett, R., Curphy, G. (1999) Leadership: Enhancing the Lessons of Experience. Singapore: McGraw-Hill Book Co, 674 p.

5. Knowles, R., McLean, G. (1986) Psychological Foundations of Moral Education and Character Development: an Integrated Theory of Moral Development. (Eds.) Lanham: University Press of America, 364 p.

6. McIntosh, M., Thomas, R., Leipziger, D., Gill, C. (2003) Living Corporate Citizenship: Strategic Routes to Socially Responsible Business. Harlow: Prentice Hall Financial Times, 297 p.

7. Milts, A. (2000) Étika. Personības un sabiedrības ètika [Ethics of Personality and Society]. Rīga: Zvaigzne ABC, 88 lpp. (in Latvian).

8. Milts, A. (1999) Ētika. Kas ir ētika [Ethics. What is Ethics]. Rīga: Zvaigzne ABC, 60 lpp. (in Latvian).

9. Paine, L. (1997) Cases in Leadership, Ethics, and Organizational Integrity: A Strategic Perspective. Boston: Irvin, $337 \mathrm{p}$.

10. Robbins, S. (2000) Managing Today! 2nd ed. Harlow: Prentice Hall, 651 p.

11. Siccone, P. (1998) Corporate Social Responsibility. Corporate Communications for Executives (Eds.) M. Goodman. Albany: State University of New York Press, 329 p.

12. Perrinjaquet, A., Furrer, O. (2005) Individual Values and Sensitivity to Corporate Ethical Responsibility of Business Students and Managers. Working paper 0502, April 2005. http://www.hec.unil.ch/iumi/ iumi/WP/0502.pdf (02.06.2005.).

13. Scholtens, B. (2009) Corporate Social Responsibility in the Banking Industry. Journal of Business Ethics No 86, p. 159-175.

14. Velasquez, M. G. (2002) Business Ethics: Concepts and Cases. New York: Prentice Hall, 528 p.

15. Weyzig, F. (2009) Political and Economic Arguments for Corporate Social Responsibility: Analysis and a Proposition Regarding the CSR Agenda. Journal of Business Ethics No 86, p. 417-428.

16. Уткин, Э. (1998) Этика бизнеса [Business Ethics]. Москва: Зерцало, 254 с. (in Russian).

Dr. oec. Jānis Strautmanis

BA School of Business and Finance

Address: K. Valdemāra 161, Rīga, LV-1013

Phone: +371 67322605

Fax: +37167320620

E-mail: janis.strautmanis@ba.lv
Dr. habil. psych., Dr. oec., Māra Vidnere

Riga Teacher Training and Educational

Management Academy

Address: Imantas 7. līnija 1, Rīga, LV-1083

Phone: +37167808010

Fax: +371 67808034

E-mail: mvidnere@navigator.lv 